\title{
THE HEROIC ARCHETYPES AND THE REINVENTION OF ASWANG CHARACTER IN SEGUNDO MATIAS' MOYMOY LULUMBOY ANG BATANG ASWANG
}

\author{
Mary Ann Alcantara Illana* \\ School of Humanities, Ateneo de Manila University, Katipunan Avenue, Loyola Heights, Quezon City, \\ Philippines
}

\section{ARTICLE INFO}

Keywords:

Aswang lore

Aswang reinscription

Heroic archetype

Urban legend

\section{Article History:}

Received: 25/09/2020

Accepted: 20/05/2021

Available Online:

$31 / 05 / 2021$

\begin{abstract}
A B S T RA C T
Marginalized and queer heroes are being recognized in the resurgence of various types of characters in contemporary hero narratives. In challenging the normative conventions, there are heroic values in the ambiguous presentation of their character which are revived and valorized based on the heroic archetypes presented in the story. Given this, how do we reconcile the normative conventions of hero attributed to queer and deviant representation of his character and heroic deeds? This paper analyzes the contemporary work of Segundo Matias' Moymoy Lulumboy: Ang Batang Aswang. Patterned from Joseph Campbell's normative structure of hero's journey, which models the representation of various nature of character heroes and their established heroic archetypes, this study revealed that a category of heroic deviant exists in portraying character hero in the revival of Aswang lore in contemporary urban legend. Furthermore, this paper affirms that the resurrection of the archetypal pattern and the marginal presentation of the hero and his journey present a re-inscripted image of Aswang from a "rigidly static" to a semi-heroic ascension.
\end{abstract}

2442-305X / (C) 2021 The Author, this is open access article under the (CC-BY-NC) license (https://creativecommons.org/licenses/by-nc/4.0/), DOI: 10.19105/ojbs.v15i1.3828

\footnotetext{
$\overline{\text { * Corresponding Author: }}$

Email address: mary.illana@obf.ateneo.edu (M. A. A. Illana)
}

\section{A. Introduction}

Characterized by the revival of Philippine mythology stories, Aswang has been portrayed and reinvented in varied forms. The resurgence of its lore has increasingly become part of the landscape of $21^{\text {st }}$-century urban narratives, where the reconstruction of Aswang image also becomes a popular trope in the media landscape. Consequently, this supernatural creature has now occupied the literary discourse and the cinema and television, creating varied depictions and modes of representations. ${ }^{1}$ Varied media platforms have widened the context about

\footnotetext{
${ }^{1}$ Rolando Tolentino, "Shake, Rattle and Roll Horror Franchise and the Specter of Nation-Formation in the Philippines," Humanities Diliman 13, no. 1 (2016): 134-52.
} 
this "creepy creature." Similarly, versions of the Aswang stories are seen in movie series and cross-genre films, including the movie series "Shake, Rattle and Roll" in 1990, Aswang in 1992, Ang Darling Kong Aswang in 2009, and Corazon: Ang Unang Aswang in 2012. Also, its lore has been translated into queer depictions and experimental images that adapt to the aesthetic pattern of contemporary urban narratives.

As Aswang image is revived in 21stcentury settings, its stories become the sites and spaces from which the signification of monstrous image is purposively presented and examined. Its cultural resonance is also influenced by the reconstruction of social structure and becomes the locus of social critique. In addition, contemporary Aswang depictions in different horror films and literary texts expand the multiplication of its symbol and challenge its existing taxonomy. ${ }^{2}$

What follows are accounts of this revival that focus on Manananggal (viscera-sucker) as one of the classifications of Aswang. These accounts relate to the reinscriptions of Aswang image and its portrayal in various discourses such as film, novel, and art. From a serious and traditional portrayal, the contemporary Aswang described by Kentaro Azuma in his article "In Search of Aswang: A Ghost Story, Monster and Sorcerer in Philippine Society" is now flavored with humor and "enhanced factors of romance." ${ }^{3}$

\footnotetext{
2 Tolentino, 139,149.

${ }^{3}$ Kentaro Azuma, "In Search of Aswang: A Ghost Story, Monster and Sorcerer in Philippine Society |
}

Film critic Bliss Cua Lim in her article "Queer Aswang Transmedia: Folklore as Camp," analyzes the queering image of Aswang in the following texts: 2011 comic novel Si Amapola sa 65 na Kabanata by Ricky Lee, mainstream film Mga Bata ng Lagim in 1964, and an amateur digital video Amabilis 2 in 2011. ${ }^{4}$ In the queering of Aswang image, Ricky Lee's comic novel Amapola sa 65 na Kabanata replaces the image of female viscera-sucker (Manananggal) to "Bakla Manananggal" and portrays him as a heroine, a lover, a family member, a moodshifter, a transgender, an urbanized figure, a political being, a funny adapting mythical creature, and Aswang as similar to us.

Lim argues that the queering of Manananggal results in the distortions of the normative and traditional portrayal of the cultural figure of Aswang wherein Manananggal depicts an image of a deviant woman as the bearer of monstrosity, a process that advocates for the "acceptance of marginality and difference" in the discursive inversion of Aswang image. ${ }^{5}$ In short, this iconic monster figure has been destabilized in mainstream film and fiction and has been "flamboyantly queered."6

In addition, the association of Manananggal with female monstrosity is

\footnotetext{
Kyoto Review of Southeast Asia," October 3, 2012, https://kyotoreview.org/issue-12/in-search-ofaswang-a-ghost-story-monster-and-sorcerer-inphilippine-society/.

4 Bliss Cua Lim, "Queer Aswang Transmedia: Folklore as Camp," Kritika Kultura, no. 24 (2015): 180-127, https://doi.org/10.13185/KK2015.02407.

${ }^{5} \operatorname{Lim}, 183$.

${ }^{6} \operatorname{Lim}, 183$.
} 
challenged by a "risky appropriation." Lim argues that its "forceful, funny and joyous" reinvention in its queer existence was part of "visibility politics" and "temporality," which turn "an older figure of horrific misogyny into a newer figure of comic homophobia or transphobia." Thus, the appropriation of the word "queer" revises how it is used and defined. Consequently, its nineteenth-century feminized, monstrous, and abject image is reinforced, and the biased notions of Kabaklaan are intensified.

Lim's arguments contribute to understanding the power dynamics in relation to the continuous visibility of gay culture in our society whereby homosexuality is not anymore characterized as a "grave" sin but is becoming part of gender classification.

The "Bakla Manananggal" body, then, becomes a political body that shows the intersecting forces of gender, class, culture, and identity, which reconcile sexual politics and proper sexual behavior. With the distortions in the normative depictions of Manananggal, the revival of Aswang image in $21^{\text {st }}$-century literary context becomes the site of power relations that define the body and culture as a whole.

Subsequently, the politics in the promotion of sexual liberation in the queering depiction of Manananggal is also found in the innovations of contemporary arts. Alpesh Kantilal Patel, in his article "The Art of Queering Asian Mythology," examines the generative nature of

${ }^{7}$ Lim, "Queer Aswang Transmedia."186. artworks that deal with LGBTQ themes across South Asia and Southeast Asia. It discusses how the visual depictions of a normative image of sexuality are destabilized. $^{8}$ The article also presents how world mythology is reimagined in exploring these themes in artworks that "use[s] the lens of Asian mythologies to queer and rework traditional concepts of sexuality."

One example of the reworking of Philippine mythology can be found in the video of Australian artists Justin Shoulder and Bhenji Ra titled Ex Nilalang. The title suggests "creature" or "to create" and the inclusion of "ex" is derived from Latin, meaning "out of" and "out from" which connotes that the often-maligned creature "can [also] be creator rather than destroyer."10 In the video, a close-up shot of Manananggal is featured in the section titled Balud. Its image, which is described as a beautiful woman by day and a monster by night, is personified by a Bakla performer named Jai Jai. ${ }^{11}$

According to Patel, the sympathetic portrayal of Manananggal is emphasized to connect her to other marginalized populations in the folkloric traditions who are often maligned. ${ }^{12}$ In the same manner, the siren-mermaid Dyesebel, which depicts the existence of trans-community

\footnotetext{
${ }^{8}$ Alpesh Kantilal Patel, "The Art of Queering Asian Mythology," in Global Encyclopedia of Lesbian, Gay, Bisexual, Transgender, and Queer (LGBTQ) History, ed. Howard Chiang et al., 10th ed. (Michigan: Gale: A Cengage Company, 2019), 127-34.

${ }^{9}$ Patel, 127.

${ }^{10}$ Patel, 129.

${ }^{11}$ Patel, 129

12 Patel, 129.
} 
portrayed in the second part of the video, also highlights "the coming together of LGBTQ subjects in nightclubs which produce alternative communities of belonging."13 This image shows the fluid spaces for queer-based connections that liberalized the notion of sexuality. ${ }^{14}$

Patel's attempt to reframe the Manananggal goes against the biases of pre-colonial notions. He further illustrates how sexual transgressions and sexual politics thrive with the increasing visibility and acceptance of gender equality. ${ }^{15} \mathrm{His}$ arguments will help us understand how the Aswang narratives in the $21^{\text {st }}$-century context reveal literary representations of its body transformation. However, more focus is needed on the interactions of gender and class within the social space where power and resistance also exist.

Accordingly, Patel's contentions on the fluidity of gender representations in the portrayal of Aswang-Manananggal liberalize the notion of sexuality and attempt to reconfigure its naturalized and binary classification. ${ }^{16}$ In addition, the politics in the artistic representations of sexuality are correlated with the argument to dismantle the traditional reading and attitudes towards the female body depicted in the early historical narratives about Manananggal. ${ }^{17}$

\footnotetext{
${ }^{13}$ Patel, 129.

${ }^{14}$ Patel, 130.

${ }^{15}$ Patel, 130.

16 Raul Pertierra, "Viscera-Suckers and Female Sociality: The Philippine Asuang," Philippine Studies 31, no. 3 (1983): 319-37, https://www.jstor.org/stable/42633556.

17 Patel, "The Art of Queering Asian Mythology," 130.
}

Meanwhile, in her article "Performing the Body in Filipino Narratives: The Manananggal (Viscera Sucker) in Colonial Literature," Hope S. $\mathrm{Yu}$ places emphasis on the performative function of the female body as a site of power. She illustrates that the disenfranchisement of the powerful role of women during the Spanish period was achieved by the demonization of the "catalonans" or "babaylanes," and their skills in healing, midwifery, and prophecy are reversed. ${ }^{18}$

Drawing on other studies, Yu points out how female power is maligned by depicting Aswang-Manananggal as the killer of infants. ${ }^{19}$ Her act of giving and taking life is "underscored by selfsegmenting process in which the reproductive half is left behind while the upper half is engaged in death-dealing activity." $^{20}$ Also, the Spanish friars denounce the shamans because they believe that they are primitive, unchaste women, practitioners of a fraudulent religion, and above all, as the priestess of the devil. ${ }^{21}$ These negative relabeling were part of the Spaniards' desire 'to eliminate Animist religion and concomitantly any resistance to the

\footnotetext{
18 Hope Sabanpan-yu, "Performing the Body in Filipino Narratives: The Manananggal (Viscera Sucker) in Colonial Literature," UNITAS 90, no. 1 (2017): $57-73$, https://doi.org/10.31944/2017901.hosayu03.

19 Francisco R. Demetrio, "Shamans, Witches and Philippine Society," Philippine Studies 36, no. 3 (1988): 372-80, https://www.jstor.org/stable/42633102.

${ }^{20}$ Sabanpan-yu.abanpan-yu, 66.

21 Herminia Menez, Exploration in Philippine Folklore (Manila: Ateneo de Manila University Press, 1996). 91
} 
introduction of Catholicism.."22

The study by $\mathrm{Yu}$ is important because it allows us to see the function of Aswang as shown by the inversions in the meaning of Aswang-Manananggal. ${ }^{23}$ Indeed, the inversions exhibit women's power to disrupt the cycle of the patriarchal system that dominates women and defines them as passive and powerless. ${ }^{24}$

The shift and hybridity of Manananggal as a classification of Aswang accordingly suggest the fluidity of its image. ${ }^{25}$ This process will allow us to create a new approach and direction in redefining monstrosity, where new construction of image, gender, and sexuality is inscribed. As $\mathrm{Yu}$ asserts, Manananggal body "can become a crucial figure from a folk villainess to a more fluid idea of a woman." 26

Manananggal manifests the ability of a woman to carry a baby without going through giving birth. Thus, Yu argues that through the trope of the uncontained body, ideas of liberation, freedom, and subversion permeate the Manananggal stories. $^{27}$ In short, Manananggal challenges the cultural borders of identity and contributes to the realignment and

\footnotetext{
${ }^{22}$ Menez, 62.

23 Sabanpan-yu, "Performing the Body in Filipino Narratives."

${ }^{24}$ Menez, Exploration in Philippine Folklore, 62.

25 Soledad S. Reyes, "The Komiks and Retelling the Lore of the Folk," Philippine Studies 57, no. 3 (2009): 389-417, https://www.jstor.org/stable/42634017.

26 Sabanpan-yu, "Performing the Body in Filipino Narratives," 57

${ }^{27}$ Sabanpan-yu, 61
}

repositioning of cultural concepts. ${ }^{28}$ Finally, Yu's attempt to explore the traditional accounts that reconfigure the image of Manananggal provides the lens through which the demonization of Babaylanes, the domesticity of women, and the monstrification of the female body can be examined. ${ }^{29}$

The given accounts foreground the meaning and revival of Aswang stories in the reinvention of Aswang-Manananggal. These accounts contribute to understanding the scope of its representation and the landscape of $21^{\text {st }}$ century urban narratives. By analyzing the story of Segundo Matias' Moymoy Lulumboy: Ang Batang Aswang, a represented genre of contemporary urban legend, I explore the archetypes of character hero and his heroic journey in the reinvention of Aswang image. ${ }^{30}$

In this study, I propose a "monomyth reading" of Moymoy Lulumboy and adapt a queer and semi-deviant heroism concept that led to theorizing the reinscription of Aswang both as a hero and a hero in disguise. Specifically, this traces the cultural patterns about the beliefs and depictions of Aswang in the story and relates to the $21^{\text {st }}$-century landscape of urban narratives.

\footnotetext{
28 Sabanpan-yu, 61.

${ }^{29}$ Sabanpan-yu, 61.

${ }^{30}$ Segundo Matias, Moymoy Lulumboy: Ang Batang Aswang (Metro Manila: Lampara Publishing House Inc, 2014). 212-217.
} 


\section{B. Method}

The normative structure of a hero's journey, which I utilized in this study, was patterned after the American scholar Joseph Campbell. ${ }^{31}$ The monomyth reading was applied to illumine the heroic tropes portrayed by queer and deviant character hero as encapsulated in the story. In Campbell's model of the heroic journey, the typical adventure that a hero undertakes is summarized in the following archetypes: the departure, the initiation, the road to trials, the innermost cave, and the return and reintegration with the society. ${ }^{32}$

Guided by Campbell's paradigm, the analysis will illustrate the character hero's journey and the variety of progressions to achieve his goal. Significant archetypes and the corresponding purpose and functions relative to these, such as the hero's journey, the mentor, shapeshifter, and the shadow, are emphasized to illumine the development of the character. ${ }^{33} \mathrm{~A}$ formalist approach is further employed since the analysis is mainly focused on how the literary elements work together in showing the portrayal of the character hero and his heroic journey: characters, plot, conflict, and setting. This approach employed to concentrate in close reading and examine the aesthetics and the interplay of moral, social, and psychological aspects of the story.

31 Joseph Campbell, The Hero with A Thousand Faces (Princeton: Princeton University Press, 2004). 1.

32 Joseph Campbell, The Hero with A Thousand Faces (Princeton: Princeton University Press, 2004),45-63

${ }^{33}$ Campbell, 89-100.

\section{Results}

This section presents the analysis of the story, which includes the following aspects: historical background of the lower mythology; the landscape of monster hero in novel, film, and comic series; the conventions and contemporary tropes of Aswang; and the elements and archetypes found in the story. Specifically, the discussions are thematically arranged relative to the aspects explored and analyzed in the story. These consist of the following sections: (1) Revisiting the Aswang Chronicles: A Glimpse of Lower Mythology, (2) A Protagonist or a Villain: Foregrounding the Shift in Tropes of Monstrous Characters, (3) The Heroic Archetypes in Contemporary Urban Narrative: The Pattern of Moymoy's Journey, (4) Moymoy Lulumboy ang Batang Aswang: The Deconstructed Hero in the Revival of Enduring Aswang Lore, and lastly (5) Normalizing the Queer in the Portrayal of Aswang: Reconciling the Image of Contemporary Deviant Hero.

\section{Revisiting the Aswang Chronicles: A Glimpse of Lower Mythology}

The primitive Aswang is portrayed as monstrous. He is often attributed to "inhuman" and "demonic entities." ${ }^{34}$ The perpetuation of this belief originates during the Spanish conquest of the Philippines, and the earliest reference of its existence and beliefs can be traced back to the accounts of Miguel de Laorca in 1582-83. It told about the Pintados in

\footnotetext{
34 Pertierra, "Viscera-Suckers and Female Sociality," 319-37.
} 
Panay and their customs and practices. It is also believed that each regional and local context has its own special accounts as regards the existence of Aswang, particularly the Christianized places during the time of the Spanish conquest. ${ }^{35}$

In his article on Aswang Syncrasy in the Philippine Folklore, Maximo Ramos regards Aswang as a "corpse-eating mythical being," which has equivalent terms in a respective dialect of different regions. ${ }^{36}$ It is identified as "Kalag" or "Kagkag" that resembles the European ghouls regarding their appetite for the human corpse. ${ }^{37}$ Ramos further describes Aswang or Philippine vampire as "a bloodsucking creature disguised as a beautiful maiden" and "an attractive woman by day, with buxom, long-haired, and light complexioned."38

In her adaptation of Maximo Ramos' Aswang chronicles, Alta Grace de Gracia's "Aswang (Monsters) and Supernaturalism: Nocturnal Deities," which explores Aswang in Atimonan folklore, also describes Aswang as "either a man or a woman endowed with superpowers of locomotion and inhuman appetite for the voided phlegm and blood

${ }^{35}$ S. J. Ignacio Francisco Alcina, History of the Bisayan People in the Philippine Islands, trans. Cantius J. Kobak, O. F. M. and Lucio Gutierrez O. P., vol. 1 (Manila, Philippines: UST Publishing House, 2004).

${ }^{36}$ Maximo D. Ramos, The Aswang Complex in the Philippine Folklore (Quezon City: Phoenix Publishing House Quezon City, 1990). 238.

37 Margaret Magat, "Balut: 'Fertilized Duck Eggs and Their Role in Filipino Culture,"' Western Folklore 61, no. 1 (2002): 63-96, https://doi.org/10.2307/1500289.

38 Ramos, The Aswang Complex in the Philippine Folklore, 238-40. of the sick especially the tubercular ones, the fetus in the womb, as well as flesh and blood of the dying and the dead." ${ }^{39}$

Meanwhile, in Frank Lynch's Aswang Inquiry, Aswang is identified as either male or female who is "quiet and does not talk too much" and "eats the flesh of the newly dead. He/she "looks pale and thin by day" but "becomes a frightful sight" once he/she attacks a person. The power he/she possesses makes him/her capable of getting things that he/she wants, like taking long trips without paying and without being noticed. ${ }^{40}$ In addition, Lynch describes the flying Aswang (Manananggal) as "the most widely known Philippine witch that divides at the waist" and "come[s] without their trunk and limbs." ${ }^{41}$

On the other hand, de Gracia's accounts state that the Manananggal or flying Aswang uses "magic formula and ointments made of animal dung with coconut oil and a concoction of medicinal plants" to transform themselves. ${ }^{42}$ Both Lynch and de Gracia's adaptation further categorize Aswang according to its mode of locomotion: the walking Aswang (Aswang na naglalakad) and the flying Aswang (Manananggal). ${ }^{43}$

\footnotetext{
${ }^{39}$ Alta Grace de Gracia, Aswang (Monsters) and Supernaturalisms: Nocturnal Deities (Manila, Philippines: Rex Book Store, Inc., 2011). 68.

${ }^{40}$ Frank Lynch, The Aswang Inquiry (Dallas: The Anvil Pub, 1998). 5.

${ }^{41}$ Lynch, 5.

42 de Gracia, Aswang (Monsters) and Supernaturalisms: Nocturnal Deities, 71.

${ }^{43}$ de Gracia. 69.
} 
The first kind, the walking Aswang (Aswang na naglalakad), "often comes in the form of a dog" and literally "walks on the ground." ${ }^{44}$ This is considered the most common kind of Aswang, who employs many strategies in attacking his victims. Due to the acute sense of hearing that the walking Aswang has, he is able to listen to the sounds of the mourners by positioning his head on the ground. Another strategy includes the use of bad-smelling oil or ointment in his body which gives him the ability to walk with the swiftness of the wind. ${ }^{45}$ It is also believed that the power that shifts human beings to Aswang is gained or regained with the coming of darkness. ${ }^{46}$ Thus, the walking Aswang can adopt the form of the first animal that he meets so he could proceed to the house of his victim. ${ }^{47}$

The preceding accounts are significant in understanding the gradual shift in the character portrayal of Aswang from a monstrous and grotesque image to a "semi-deviant hero." Following the journey of the character hero, Moymoy, the revival of the archetypal pattern will illustrate a re-inscripted image of Aswang that assumes a new role as "hero in disguise." Together, these accounts guide the direction in understanding the dynamics of heroic archetypes found in the re-telling of Aswang lore in contemporary urban legend.

\footnotetext{
44 de Gracia, 69.

${ }^{45}$ de Gracia, 69.

${ }^{46}$ de Gracia, 70.

${ }^{47}$ de Gracia, 70.
}

\section{A Protagonist or a Villain: Foregrounding the Shift in Tropes of Monstrous Characters}

How do we reconcile a hero and a monster? In her article "Hyde the Hero: Changing the Role of the Modern-Day Monster," Erica McCrystal explores the adaptation of Hyde's character from "Stan Lee and Jack Kirby's comic book series The Incredible Hulk in 1962, Alan Moore and Kevin O'Neill's neo-Victorian comic book series The League of Extraordinary Gentlemen in 1999-2009, Steven Moffat's television miniseries Jekyll in 2007, and Charlie Higson's television series Jekyll and Hyde in $2015 .{ }^{48}$ The revival of Hyde's character as a monster hero reflects contemporary anxieties but has been repurposed for the socio-political agenda of twentieth and twenty-first-centuries adaptations. ${ }^{49}$ The barbaric rendition of his character is contrasted through his noble motivations, which illustrate heroic selflessness and love that become the most powerful weapon against true evil. In this way, the modern-day Hyde is transformed from a monstrous social reject to a savior vital to society. ${ }^{50}$

Subsequently,

Christopher McGunnigle explores the "cultural fluidity" of the monster image in his article "The Difference between Heroes and Monsters: Marvel Monsters and Their Transition into the Superhero Genre." In probing the "verbal and visual rhetoric" of the

\footnotetext{
${ }^{48}$ Erica McCrystal, "Hyde the Hero: Changing the Role of the Modern-Day Monster," University of Toronto Quarterly 87, no. 1 (March 1, 2018): 23448, https://doi.org/10.3138/utq.87.1.234.

${ }^{49}$ McCrystal, 239.

${ }^{50}$ McCrystal, 247.
} 
monsters in Marvel Monster comic book, Mcgunnigle argues that a new mediation of the monster figure illustrates the production of a much innovative portrayal of superhero. ${ }^{51}$ This popular monster category is drawn from the iterations of classical and conventional archetypes of both hero and monster, resulting in visual and rhetorical ambiguity. Accordingly, this rhetoric of Marvel monsters is galvanized not as "monsters" but as "superheroes." 52 The image of superheroes attempts to stabilize and redeem conflicts concerning the portrayal of what is heroic and what is monstrous. Thus, the commodity of culture that continuously influences the reinvention of marvel monsters positions its transmogrifying image into a newly framed superhero. ${ }^{53}$

Meanwhile, the resiliency of vampires also emerged in contemporary narratives, and the reinvention of its image has also shown several iterations in the modern, romantic vampire narrative, particularly in the movie. ${ }^{54}$ In her article, Vera Benczik explores the vampire's image as positioned within the genre of science fiction. Considered one of the exciting hybrids of Gothic Vampire, the

51 Christopher McGunnigle, "The Difference between Heroes and Monsters: Marvel Monsters and Their Transition into the Superhero Genre," University of Toronto Quarterly 87, no. 1 (March 1, 2018):

110-35, https://doi.org/10.3138/utq.87.1.110.

52 McGunnigle, 114.

${ }^{53}$ McGunnigle, 133.

54 Dijana Vučković and Ljiljana Pajović Dujović, "The Evolution of the Vampire from Stoker's Dracula to Meyer's Twilight Saga," CLCWeb: Comparative Literature and Culture 18, no. 3 (2016): $\quad 1-8, \quad$ https://doi.org/10.7771/14814374.2836 . movie I Am Legend, released in 2007, is an adaptation of the novel published by Richard Matheson in $1954 .{ }^{55}$ The novel utilizes zombies as the monstrous embodiment but later on demonstrates the changes in the portrayal of a vampire as a deconstruction of a traditional hero archetype of American culture. ${ }^{56}$ In the story, Robert Neville is characterized as far from the archetypal but in the context repositions himself to allow the readers to reconcile their moral framework against their flaws and unethical position. In this sense, the mysterious figure of the monster is ultimately humanized. ${ }^{57}$

Lastly, the intersecting relationship of hero, master, and monster recognizes the enduring role of a distorted image of monster both as a literary device and as part of the mythological background of ancient texts such as the epic, myth, and bible. ${ }^{58}$ Ryan S. Higgins' "The Good, the God, and the Ugly: The Role of the Beloved Monster in the Ancient Near East and the Hebrew Bible" examines the nature of "grotesque" and "horrifying" creatures in Ugaritic, Mesopotamian, and Hebrew Bible texts. ${ }^{59}$ In his "beloved

\footnotetext{
55 Vera Benczik, "Monsters Old and New - The Changing Faces of Otherness and in Richard Matheson's I Am Legend and Its Film Adaptation," in Tradition and Innovation in Literature: From Antiquity to the Present, ed. Pál Hegyi (Eötvös Loránd University: the Dean of Faculty of Humanities, 2020), 187.

${ }^{56}$ Benczik, 87.

${ }^{57}$ Benczik, 193.

58 Robert A. Segal, "The Blurry Line Between Humans and Gods," Numen 60, no. 1 (2013): 3953, https://doi.org/10.1163/15685276-12341251.

59 Ryan S. Higgins, "The Good, the God, and the Ugly: The Role of the Beloved Monster in the Ancient Near East and the Hebrew Bible," Interpretation: A Journal of Bible and Theology 74,
} 
monster motif," he contextualizes the critical role of the monster as a good character that shows a favorable relationship with a high god. ${ }^{60}$ As a literary device, he emphasizes how the role of a "beloved monster" reconciles this relationship to preserve the integrity of the cosmos. ${ }^{61}$ He further illustrates how the intermediary position of the monster becomes a natural extension of the monster's essence as a hybrid and 'between being'. 62 Thus, the sympathy towards the modern monsters represents them as victims of humanity's cruelty. ${ }^{63}$

\section{The Heroic Archetypes in Contemporary Urban Narrative: The Pattern of Moymoy's Journey}

In Campbell's paradigm, the hero's journey begins in the ordinary world, and his nature is identified. Initially, he is threatened by forces that disrupt his affair in the ordinary world. He has to combat his personal doubts about whether to accept the challenge or not. He tries to reconcile between the comfort in the ordinary world or the challenging road that awaits him. In the course of confusion, he meets a mentor and provides him guidance to respond and accept the challenge. He receives something important from the mentor that will provide him strength and courage to assist him in his journey. His acceptance indicates that he finally crosses the threshold between

no. 2 (2020): $132-45$,

https://doi.org/10.1177/0020964319896307.

${ }^{60}$ Higgins, 133.

${ }^{61}$ Higgins, 135.

62 Higgins, 134-35.

${ }^{63}$ Higgins, 133. staying in the ordinary world and choosing the journey he has to undergo. Commitment has now become his stronghold.

Eventually, the hero is confronted with difficulties and various tests where he gains more wisdom and a deeper understanding of his own character as a hero. This stage leads him to his ultimate goal and later on experiences a metaphorical resurrection.

Despite the tests, the hero receives a reward that could be in the form of power, knowledge, or insight. As the hero approaches his return from his journey, he experiences the difficulty of reconciling his objective from his heroic goal and eventually faces the battle in the final stage of his journey. In the end, the hero succeeds, celebrates, and brings with him the wisdom he learned and successfully reaches the point of self-realization, i.e., becoming a new person. The typical processes that are drawn from these archetypes are illustrated in a "circular diagram." Isabelle Meier, in her article "The Classic, Banished, and Negative Hero," adapted this concept of "circular paradigm" in her description of the "classic solar hero" as she explores the transformation of male heroic images but contextualized more on Jung's concept of individuation. ${ }^{64}$

In Moymoy Lulumboy, the portrayal of his heroic journey returns to the same paradigm. It attempts to derail from the

\footnotetext{
64 Isabelle Meier, "The Classic, Banished, and Negative Hero," Jung Journal 15, no. 1 (2021): 3648,

https://doi.org/10.1080/19342039.2021.1862593.
} 
established belief about his identity as Aswang and resists the traditional construct associated with its character portrayal and image..$^{65}$

How could the Aswang character be an embodiment of heroism? How does it shape the landscape of contemporary urban legend? These questions point us to reconciling the cycle of a classic hero in the unfolding of events that shape the changing faces of a marginalized character. ${ }^{66}$ Segundo Matias addressed the ambiguous portrayal of his Aswang character by allowing his readers to immerse themselves in the lower world. ${ }^{67}$ The intersecting features of cosmogonic myth, etiological elements, cosmic architecture, and cosmic disaster build the succeeding accounts establish the hero's adventure structure. ${ }^{68}$ These features provide the basic premise concerning the conventional pattern of heroic archetypes employed in the story.

The narration begins with the prologue on the existence of Gabun: a place of order and harmony. Every Tibaro (Aswang and other supernatural creatures) experiences the abundance of nature and the environment. Discord enters when Buhawan, one of the Tibaros, steals the Ginto ng Buhay in Panalturan. The Ginto ng Buhay is essential among

\footnotetext{
${ }^{65}$ Kelly Bergstrand and James M. Jasper, "Villains, Victims, and Heroes in Character Theory and Affect Control Theory," Social Psychology Quarterly 81, no. 3 (2018): 228-47, https://doi.org/10.1177/0190272518781050.

${ }^{66}$ Bergstrand and Jasper, 236.

${ }^{67}$ Matias, Moymoy Lulumboy: Ang Batang Aswang, 1.

${ }^{68}$ Francisco Demetrio, "Creation Myths among the Early Filipinos," Asian Folklore Studies 27, no. 1 (1968): 41-79, https://doi.org/10.2307/1177800.
}

the Apos (gods and goddesses) because it provides power for their immortality. Amang Bathala punishes the Tibaros, dismisses them in Sibol Encantada, and transforms their appearances into ugly creatures. They also experience extreme hunger during the night of Dugon, and to satisfy their hunger, they eat the other Tibaros. Because of Buhawan's disobedience, the Tibaros were introduced to the idea of death. ${ }^{69}$

Meanwhile, Matias has also led us in an exploration of the underworld using the image of Gabun, which is divided into three major islands: Sibol Encantada, Malasimbo, and Dalumdum. The Sibol Encantada is the biggest island and the place where the gods and goddesses reside. The existence of Aswang community that Matias portrays resembles the formation of the world in the cosmogonic myth. Etiological elements such as the Tibaros' existence, their appearance transformation, the existence of suffering and evil, the consequences of disobedience, and the birth of death, are depicted in the events that shape the story. $^{70}$

Matias has also revealed a version of the cosmic architecture using the image of Balete tree. This form of a "World Tree" is also similar to the Hebrew mystical tradition's "Tree of Life," which unites the upper and the lower world. Many cultures

\footnotetext{
69 Francisco Demetrio, "The Religious Dimensions of Some Philippine Folktales," Asian Folklore Studies 28, no. 1 (1969): 51-76, https://doi.org/10.2307/1177780.

70 Brevard S. Childs, "The Etiological Tale ReExamined," Vetus Testamentum 24, no. 4 (1974): 387-97, https://doi.org/10.2307/1517173.
} 
resort to the symbolic meaning of trees which provide the connection between heaven and earth "and are sometimes believed to be the home of the spirits." ${ }^{71}$ In the story, Moymoy enters inside a Balete tree when he returns to Gabun. The Balete tree serves as the central pillar or axis between Moymoy and Gabun. Meanwhile, Dalumdum is described in the story as a very dark place and coincides with Buhawan and Alangkaw as the embodiment of evil side.

As Moymoy follows the normative paradigm, his heroic journey represents more of an emotional and psychological response from his personal decision, leading to a deeper understanding of his nature. The depictions of his character as a contemporary Aswang and his journey revive the traditional heroic paradigm. This journey primarily focuses on Moymoy's search for his existence. He has been the underworld hero, but as a child, he remains traditionally unrecognized in the world of human beings, as "Buntaw" (tao).

Moymoy's ordinary world in the rising action of the story has not been comfortable. Nurtured by his foster parents Tracy and Edcel, his childhood life has not been as happy as it should be. The death of Edcel, the loss of Tracy, and the treatment given by Aunt Bella disrupt the life he had in Amalao (mundo ng mga tao) which urges him to join Montar in Gabun (mundo ng mga Aswang). During his arrival in Gabun, he sees how ordinary life could be and how Gabun resembles

${ }^{71}$ Matias, Moymoy Lulumboy, 43.
Amalao. He reached the peak of acceptance about his nature and identity after dealing with his confusions.

Moymoy's return to Gabun becomes a symbolic action in overcoming his inner struggle to understand his nature. In the same way, this may also mean how Matias implicitly recognizes the importance of confronting one's shadow that makes one heroic. This embodies Moymoy's struggle to attain a deeper insight about himself which contributes to understanding the social implications of his nature and identity. However, the ambiguity that can be seen in Moymoy's struggle as Aswang hero is a depiction of a normative human struggle that could be connected to his "nature". Having a dual identity, Moymoy disengages his characteristic as a normative hero from becoming an Aswang in Gabun.

Moymoy has also reached the refusal stage as he is frightened by the obligation he needs to undertake. It escalates when he begins to realize that the Tibaros of Gabun need his help. Ibarong Saryo enlightens him and his eagerness to fight Buhawan compels him to undergo a rigid practice in the use of his Diwani (the power to transform). Through the assistance of Ibalong Saryo and Wayan, his mentors, Moymoy can overcome his fears and become firmer in his conviction of fighting Buhawan.

Three significant realities about Moymoy's true identity contribute to possessing this system of positive values and accepting his role: the revelation about his true parents, the knowledge of having a twin brother, and the role he has 
to accept as a hero in Gabun. These have intensified his commitment to fight Buhawan and bring back the Ginto ng Buhay in Panalturan. These are also reestablished after discovering that Alangkaw is his twin brother. His acceptance of the reality of his true identity also serves as an internal force to confront his enemies. To fight Buhawan becomes his greatest "ordeal" where he is about to be defeated. By entering into the realm of his nature as a Tibaro, he is conditioned to be committed to his journey. Thus, self-sacrifice is shown as one of the primary elements of his heroic acts. Aside from power, he also possesses positive values and the determination to pursue his journey.

Finally, the hero's task to recommit himself to the completion of his journey is achieved by accepting returning to the ordinary world. In the story, Moymoy has completed his journey and return to Amalao. It becomes an internal struggle because he needs to choose between staying in Gabun or staying with his mother Tracy in Amalao. The "resurrection" that has occurred in the story relates to the enlightenment he experienced after confronting his own "shadow." His own transformation has been the result of his battle between good and evil.

Moymoy restores balance in Gabun, but his struggle remains in the world of the Buntawi (tao) in Amalao. The discovery of his own existence has been resolved in Gabun but remains a mystery in Amalao as he interacts with the Buntawi (tao). Even then, Moymoy is challenged to embark on his new journey in Amalao. He reaped the reward of overcoming his fear and survived death. His discovery about his own greatest power and his reconciliation with his true identity has become one of the greatest rewards he received. Consequently, he succeeded against Buhawan and restored Gabun to its peaceful state.

In addition, the cosmic disaster that the Tibaros faced in Gabun is directly linked to the cosmogonic theme in myth. Born from a Tibaro father named Ronaldo and an apo or goddess named Liliw, Moymoy attributed a "semi-divine origin." Unlike some versions of folktales or legends, this character quality of Moymoy shifts the trope of Aswang and elevates as a "semi-god creature."72

The result of Liliw's sexual transgression with Ronaldo also establishes the tripartite division among gods, humans, and the world when Amang Bathala punished her. ${ }^{73} \mathrm{~A}$ version of such cosmic disaster is also depicted in an Aboriginal myth in Northern Australia where a "catastrophic flood" was caused by two young sisters who had sexual union with two men.

Moymoy's journey has also provided ideas on the origin of misfortune because his existence is brought by the "forbidden love" that has emerged between Liliw and

\footnotetext{
72 Demetrio, "The Religious Dimensions of Some Philippine Folktales," 51-76.

${ }^{73}$ Charles J-H Macdonald, "Folk Catholicism and Pre-Spanish Religions in the Philippines," Philippine Studies 52, no. 1 (2004): 78-93, https://www.jstor.org/stable/42633685.
} 
Ronaldo, his parents. ${ }^{74}$ The intercourse theme between the two is an important archetype to emphasize since it also provides the context of understanding the destruction of the Tibaros in Gabun. This theme of the forbidden sexual union has clearly demonstrated how cosmic catastrophe is linked to the etiological elements that have been mentioned. Because of the "wrongful unions", Liliw is punished and forced to leave Sibol Encantada. This coincides with Buhawan's disobedience so that the supernatural intervention becomes emergent both in the last part of the story where Amang Bathala causes the destruction of Buhawan, who eventually died in the story.

By responding to the call to fight Buhawan, Moymoy restores the place in Gabun and achieves what Pierce refers to as "humanity's equilibrium." 75 This is associated with Campbell's "macrocosmic triumph" because of the regeneration in the hero's society. ${ }^{76}$ Hence, Moymoy becomes the "hope" and "the symbol of the divine creative and redemptive image" that restores the order and peace in Gabun. $^{77}$ Indeed, Matias revives the notion of the traditional battle between good and evil faced by the Tibaros in

\footnotetext{
${ }^{74}$ Demetrio, "The Religious Dimensions of Some Philippine Folktales," 43-45.

75 Sarah E. Pierce, "From Demon to Daimon: A Mythic and Depth Psychological Analysis of the American Hero Vampire" (Dissertation, Pacifica Graduate Institute, 2012), http://pqdtopen.proquest.com/doc/1040729888.html ?FMT=ABS

${ }^{76}$ Campbell, The Hero with A Thousand Faces, 35.

${ }^{77}$ Campbell, 47.
}

Gabun (mundo ng Tibaro) as well as in Amalao (mundo ng tao). ${ }^{78}$

\section{Moymoy Lulumboy ang Batang Aswang: The Deconstructed Hero in the Revival of Enduring Aswang Lore}

Coming to this point, the portrayal of Moymoy makes his heroic identity ambiguous. He emerges as a transformational character in the context of his own heroic cycle, i.e., showing his monstrous and human nature. His journey also shows the intersecting concept of heroism and morality that paves the way to reconciling human flaws. ${ }^{79}$ In the realm of this heroic cycle, Benjamin Van Tourhout proposed a heroic cycle where he included a category of hybrid hero in the context of theatre performance. A hybrid hero is defined as a character that combines features from both heroes and villains. ${ }^{80}$ Concerning this, the ambiguous nature of Moymoy challenges the depictions of his character as the contemporary hero narratives begin to accommodate the rebirth of another "peripheral character hero." 11

This entrance to the contemporary heroic portrayal of Aswang addresses its

\footnotetext{
${ }^{78}$ Matias, Moymoy Lulumboy: Ang Batang Aswang, 51.

79 Lisa Arellano, "The Heroic Monster: Dexter, Masculinity, and Violence," Television \& New Media 16, no. 2 (2015): $131-47$, https://doi.org/10.1177/1527476412450192.

80 Benjamin Van Tourhout, "The Hybrid Hero: A Contagious Counterexample," Journal of Humanistic Psychology 59, no. 4 (2019): 540-67, https://doi.org/10.1177/0022167817718424.

81 Bergstrand and Jasper, "Villains, Victims, and Heroes in Character Theory and Affect Control Theory," 228.
} 
potential integration into our level of consciousness. The heroic pattern of Aswang resembles our own journey, and the cultural individuation that Moymoy underwent indicates both personal and collective cultural encounters. ${ }^{82}$ As we participate in understanding what is "hidden" in the lower world, we are challenged to embark on conscious recognition of the existence of mythical creatures in the contemporary world. Matias has partly deviated from the traditional cosmic representation of the underworld often described in Aswang lore as "a place of death or a metaphorical encounter with the dark side of self." ${ }^{83}$ It is infused with creation of myths, including the description of how the Gabun came, the cosmos creation and its existence in the Aswang community, the God and supernatural presence, and the existence of the "Apos." 84

In line with this, chaos and order in Tibaros's community are also emphasized where Buhawan stole the Ginto ng Buhay, which separates humans from God and the world. ${ }^{85}$ This cosmogonic theme is a significant feature utilized by Matias in the reconstruction of the underworld. ${ }^{86}$ Moymoy's journey is an encounter with

\footnotetext{
82 Joy Christine O. Bacwaden, "Lumawig: The Culture Hero of the Bontoc-Igorot," Philippine Studies 45, no. 3 (1997): 329-52, https://www.jstor.org/stable/42635050.

${ }^{83}$ Matias, Moymoy Lulumboy: Ang Batang Aswang, 8.

${ }^{84}$ Matias, 1.

85 Demetrio, "Creation Myths among the Early Filipinos," 43-45.

${ }^{86}$ Matias, Moymoy Lulumboy: Ang Batang Aswang, 173.
}

the dark side of being a Tibaro, but it has also become an encounter with truth.

In addition, the sacrificial process was seen when Liliw keeps Moymoy away from Gabun to protect him and the Panalturan from Buhawan. A voluntary recreation of the Aswang community in Gabun follows a destructive model where Amang Bathala intervenes in killing Buhawan. Lightning strikes the map held by Buhawan, and the forces of wind, light, water, and earth destroy him.

How do we explain the normative heroic paradigm to accommodate a representation of a deviant hero? How does it reflect our own cultural psyche about Aswang? The journey of Moymoy is both a challenge to the personal and cultural growth of the unconscious. Matias emphasizes the same cycle that humans also experience, i.e., the birth of Moymoy, the revival of life, the birth of death, and the idea of the destruction of the Aswang community in Gabun. Similarly, Alangkaw as the twin brother of Moymoy relates to the archetype of shadow since he is represented as the darkest desires, untapped resources, or even rejected qualities of [Moymoy's] past. ${ }^{87}$

Moymoy's identity as Aswang also implies the dark side and shadow of being a hero. He could also be attributed to the character of a tragic hero because he was able to see the cause of his own downfall against his twin brother Alangkaw who took revenge brought by his false judgment about his identity (hamartia).

87 Campbell, The Hero with A Thousand Faces, 179. 
Because of this, a "reversal of fortune" also took place in Alangkaw from being a "hero" in Dalumdum to becoming an "ordinary hero" in Gabun (peripeteia). His recognition of his false judgment resulted to the reversal of his role (anagnorisis) brought by his taking pride as the hero of Dalumdum (hubris) and led him to lose a fight with his twin brother, Moymoy. In the same way, Buhawan could be placed in this context. However, his death cannot be considered honorable since it was not courageously accepted.

The dualistic identity exemplified by Moymoy features his complementary relationship with his twin brother Alangkaw. This is also true with the character traits of Buhawan, disguised as Ferdinand Brazil in the world of Buntawi (tao), the leader of Filipinas Mining Corporation, and personified as the Dark Side. Having reared on the island of Dalumdum, Buhawan has conditioned Alangkaw's mind to embody an evil projection.

In addition, Alangkaw is also a mirror of Buhawan's evil side. Both have worn the shadow mask that has caused their own destruction. While the shadow may also represent positive and "admirable and redeeming qualities," the suppressed and unrepressed qualities by Buhawan and Alangkaw connote disobedience and arrogance that cause their own destruction. As a "trickster," he also tries to disrupt the status quo that led to chaos. ${ }^{88}$

${ }^{88}$ Michael P. Carroll, "The Trickster as SelfishBuffoon and Culture Hero," Ethos 12, no. 2 (1984): 105-31, https://www.jstor.org/stable/639961.
Moymoy re-creates the conventional beliefs about Aswang by elevating the concept of power and discourse of heroism not only in his ability to transform but more importantly, in the reinvention of his nature and identity. ${ }^{89}$ This shows that in the aspect of being a trickster, his "Aswanghood" could be seen as an "archetypal boundary-crosser" that shows an ambivalent quality in understanding the projection of his dual identity. ${ }^{90}$ It gradually revolutionizes the traditional conventions of hero and elevates a monstrous character that attempts to valorize the representation of archetypal hero and his journey. Hence, Moymoy as a culture hero in Gabun becomes a "trickster" and a denied hero in Amalao. ${ }^{91}$

Furthermore, Moymoy embodies the world of Aswang while the disobedience and arrogance of Buhawan and the other Tibaros in Amalao still show the metaphorical meaning associated with Aswang. Their existence has been reinvented as it resembles the story of the Fall of Adam and Eve. Thus, Aswang's existence in Amalao implies that humans continuously interact with Aswang (Tibaro), who transforms and disguises himself as a normal human being (Buntawi). This story of Matias forms part of the "cosmogonic myth" that discloses the formation of the community of the

\footnotetext{
${ }^{89}$ Tison Pugh, “The Queer Narrativity of the Hero's Journey in Nintendo's The Legend of Zelda Video Games," Journal of Narrative Theory 48, no. 2 (2018): 225-51, https://doi.org/10.1353/jnt.2018.0009.

90 Pugh, 233-34.

91 Carroll, "The Trickster as Selfish-Buffoon and Culture Hero," 105-7.
} 
Tibaros (the Aswang's community). ${ }^{92}$ Thus, with Moymoy, a community of Aswang is also confined in a code of behavior between good and evil. ${ }^{93}$

Along with this, the portrayal of Buhawan shows that Aswang resurrects and hides in high walls of private subdivision in Forbes Park, does not eat flesh nor sucks blood, instead torments body and ruins the morality of the people he interacts with. $^{94}$ Thus, the contemporary Aswang that Matias emphasizes in the character of Buhawan and his aristocratic appearance destroys human dignity and reveals that the real Aswang is walled in palaces and mansions, ransack the wealth and eventually destroys our environment. ${ }^{95}$ The monstrous image of Aswang in the persona of Buhawan has functioned metaphorically in ascribing it to his character, which resembles a "Draculian archetype," i.e., "aristocratic, seductive, intelligent, and utterly sinister" creature. ${ }^{96}$ Similarly, Buhawan has become the antithesis of Moymoy's nature. While Moymoy has redeemed the monstrous nature of Aswang in Gabun, Buhawan destabilized this image to become the aristocratic Ferdinand Brazil in Amalao.

\footnotetext{
92 Matias, Moymoy Lulumboy: Ang Batang Aswang, 10.

93 Demetrio, "The Religious Dimensions of Some Philippine Folktales," 43-45.

94 Yoshitaka Inoue, "Contemporary Consciousness as Reflected in Images of the Vampire," Jung Journal: Culture \& Psyche 5, no. 4 (2011): 83-99, https://doi.org/10.1525/jung.2011.5.4.83.

95 Inoue, 88-91.

96 Pierce, "From Demon to Daimon: A Mythic and Depth Psychological Analysis of the American Hero Vampire," 1.
}

Finally, religion plays a significant role in the revival and alignment of our beliefs about Aswang. ${ }^{97}$ This story of Matias proposes a contemporary portrayal of Aswang, and its significant deviation forms part of the landscape of his Aswang character, which focuses on the spiritual and moral attribute rather than the bodily destruction. The divine intervention and providence serve as religious undertone embodied in the role played by Amang Bathala. $^{98}$ Matias intensifies the interdependence of the upper and the lower world, where the environment in Gabun and the spirits that reside in them have direct connections with humans in Amalao. ${ }^{99}$ Also, the anthropomorphized version of Liliw makes us understand that the God perceived in Gabun is the same loving and merciful God who is also in charge of the underworld. ${ }^{100}$

Indeed, Matias attempts to elevate the cultural constructs of Moymoy as Aswang from a "rigidly static" misconception to a "semi-heroic ascension." The resonant heroic themes that Moymoy exhibit challenge the typology of heroism where the character hero is transfigured. Moymoy attempts to redeem the unconscious image of Aswang and strives to be recognized as human. His image is metamorphosed as a child who needs to confront his crisis and

\footnotetext{
97 Demetrio, "Shamans, Witches and Philippine Society," 373-76.

${ }^{98}$ Demetrio, "The Religious Dimensions of Some Philippine Folktales."

${ }^{99}$ Matias, Moymoy Lulumboy: Ang Batang Aswang, 1 .

100 Demetrio, "The Religious Dimensions of Some Philippine Folktales," 57-59.
} 
shadow. His heroic journey implies that the same confrontation is needed to achieve maturity. Thus, the journey of Moymoy is an emotional and psychological representation of his response to pursue his journey.

\section{Normalizing the Queer in the} Portrayal of Aswang: Reconciling the Image of Contemporary Deviant Hero

Moymoy Lulumboy, as another variant of Aswang lore, mirrors some patterns and beliefs about Aswang. The dualistic identity of Moymoy, as a Tibaro (Aswang) and a Buntawi (Tao) makes a "contentious aspect" of his heroism. ${ }^{101}$ Loren Barbour probes a similar idea concerning heroism in the reinvention of a non-normative identity in a graphic novel titled Nimona in her article 'Nemeses! Dragons! Symbolism!': queering the fantasy hero narrative in Nimona. As a "teenage shapeshifter," Nimona can be placed alongside the seminal definition of a monster and a "flawed hero." Thus, her shapeshifting ability accommodates the pivotal role of being a "hero, villain, and a monster."102

Following this, Moymoy exhibits the conventional and the normative archetypes of a hero that becomes "nonnormative." The nature of his character gradually altered the image of Aswang through the heroic journey that he has

\footnotetext{
101 Bacwaden, "Lumawig," 329.

102 Loren Barbour, "'Nemeses! Dragons! Symbolism!': Queering the Fantasy Hero Narrative in Nimona," Journal of Graphic Novels and Comics, June 25, 2020, 1-13, https://doi.org/10.1080/21504857.2020.1786418.
}

exhibited in his return to Gabun. At the same time, the heroic struggle that he has overcome to fight Buhawan and revive Sibol Engcantada has contributed to the rise in perceptions about Aswang. Thus, the mythic thread or pattern of Aswang has turned to the heroic character to save the Tibaros from total destruction. In line with this, Segundo Matias realigns Moymoy as a normative hero. In examining his traits in relation to his twin brother Alangkaw, contrasting qualities are found that make the first a hero and the latter a villain. ${ }^{103}$

Conversely, Alangkaw is considered a hero in Dalumdum, and his heroic deeds are drawn from false misconception of his identity and power. The challenging growth in our perceptions about Aswang and "the inner landscape of human psyche has become the contemporary 'battleground' for heroes and monsters alike." ${ }^{104}$ In this regard, the journey of Moymoy becomes a worthwhile metaphor to explore also the realm of our consciousness about Aswang. His heroic journey represents the same quest that humans have, thus becoming less and less of an Aswang but a depiction of a normal human being. Moymoy's character proposes a more humane perception yet also warns us that the adaptive and "gruesome" image of Aswang in the character of Buhawan could still deceive us. His return to Amalao, which entails the

\footnotetext{
103 Matias, Moymoy Lulumboy: Ang Batang Aswang, 134.

104 Pierce, "From Demon to Daimon: A Mythic and Depth Psychological Analysis of the American Hero Vampire," 5.
} 
integration of his nature as Buntawi (tao) and as a Tibaro (Aswang), challenges him to embrace who he is, thus, showing a continuous movement prevailing cultural orientation that he had about Aswang.

In line with this, the process of Moymoy's individuation makes us understand the direct connection and relationship that the upper world and the lower world have. The Gabun is a society with its own cultural ideals and values just like in Amalao. Moymoy's adventure only shows that to uphold one's value is to grow in understanding his/her personal and cultural background. Matias provides a context of confronting our shadow on what is unacceptable about Aswang. This has resulted in the "symbolization of the Monstrous other" where "the shadow can be personal, cultural (indicating what an entire society hates or disowns) or even archetypal. ${ }^{105}$ Moymoy's journey to Gabun makes him understand what lies deep within and, in the process, embraces the dark side of his nature.

Matias' reconstruction of Aswang into a "culture hero" among its own community in Gabun overlaps with the "culture hero" that the "Buntawi" in "Amalao" perceives to be. ${ }^{106}$ Moymoy, as an "anthropomorphic Aswang" in Gabun, becomes the hero who is willing to confront the old, outworn ways of being to facilitate both personal and cultural growth. ${ }^{107}$

\footnotetext{
${ }^{105}$ Pierce, 27.

106 Bacwaden, "Lumawig," 329-30.

107 Pierce, "From Demon to Daimon: A Mythic and Depth Psychological Analysis of the American Hero Vampire," 195.
}

The dark side of Aswang is still highlighted in the contemporary setting and subverts the concept of heroism through the character of Moymoy and his twin brother Alangkaw. It creates a paradox in understanding heroism based on what the normative pattern implies. However, Moymoy can only attain redemption by resisting the established norm on Aswang. From a monstrous to a queer portrayal, Matias gradually reinvents the Aswang image in a "less pure creature of darkness" to a more humane image which resembles the same struggle of searching the meaning of one's existence. ${ }^{108}$ Reconstructing his rhetoric is a technique that allows the monster image to transform and shift into a hero.

Finally, the heroic quest and the transformation of Moymoy encapsulate the cultural psyche of Aswang and call for a new rendition of the hero as placed by Matias in the intersecting features of his cosmogonic myth in Gabun and the world of Buntawi in Amalao. ${ }^{109}$ The contemporary settings he utilized in the story set a reiteration of the metaphor associated with contemporary Aswang who is already walled in high buildings and has adapted a modernized living. This trope challenges the nature of heroes and monsters as we struggle to embrace a cultural reorientation on the notion of monstrosity. Segundo Matias, then, bridges the barriers between the established norms of hero and the

108 Higgins, "The Good, the God, and the Ugly," 134, 135.

${ }^{109}$ Bacwaden, "Lumawig," 329-30. 
derogatory label attached to Aswang. By confronting this rhetoric, Moymoy's character becomes part of the morphology of the representations of Aswang in the $21^{\text {st }}$ century.

Derived from the given analysis, the heroic quest of Moymoy follows the same paradigm, i.e., his decision to leave Amalao and his journey to Gabun; his battle with Buhawan and his twin brother, Alangkaw; the restoration of peace and order in Gabun, and his successful return in Amalao. All these illustrate the structure of his adventure. The transformation of his identity is flavored with cosmogonic myth, cosmic architecture, etiological elements, and elements of cosmic disaster that also shape the creative construction of the plot. Gleaned from this analysis, the story of Moymoy captures the mythic and historical construction of Aswang image and the heroic pattern of a character hero. These components link one feature to the other in order to understand the literary nature of Aswang as it explains the development of the character's "semiheroic ascension."

Built upon Alcina, Ramos', Pertierra, and Lynch's descriptions of Aswang as a local paradigm, the prominent features which emerged in the story of Moymoy manifest the continuity of traits and beliefs about Aswang yet render an attempt to elevate his background as a "semi-divine" hero. Despite the reinvention of the character, there is a consistent narrative core that is retained in the repetition and variations of folklore elements found in the contemporary urban narrative. Thus, both conventional and contemporary aspects coexist in the narration and show the continuous influence of the "mythical purpose of Aswang" which renders distortions in reconciling beliefs about its image.

This paper is a response to the continuous resurgence of Aswang narratives in 21 st-century setting. It hopes to broaden and deepen our understanding and appreciation of Philippine folklore and folklore scholarship in general. Since Aswang narrative is part of the understudied and (perhaps) marginalized genre in Philippine literature, this paper will provide an avenue to expand the subscriptions to this type of narrative, hence establishing an intellectual corpora of Aswang literature that will contribute to the exploration of Philippine legends and mythology and will promote and deepen our appreciation of local literature. Furthermore, this paper will help us understand how $21^{\text {st }}$-century realities are mirrored in the revival of urban legend in $21^{\text {st }}$-century context, particularly related to Aswang. This is a valuable addition to few studies about Aswang, focusing on female monstrosity, queer Aswang transmedia, and patriarchal misogyny. It hopes to develop a literary model that explores the reinvention, distortions, or fabrications of folk narratives in 21st-century Philippine literary traditions, specifically the revival of Aswang narratives in $21^{\text {st }}$-century Philippine fiction. Moreover, this study shows the importance of interdisciplinarity of perspectives in the analysis and function of 21 st-century image of monster.

The findings of the preliminary reading of the story have to be seen in the 
light of some limitations. First, the story of Moymoy does not capture the entire representation of all urban legends about Aswang that are rewritten in the $21^{\text {st }}$ century Philippine literary tradition. Hence the analysis also seeks to extend further exploration on the aspects discussed here, namely the heroic archetypes and the reinvention of Aswang image in other contemporary urban legends. The Aswang stories are continuously being rewritten such that innovative portrayal and hybridization of its image may posit a more complex role and meaning. Second, a much in-depth study concerning the archival representations of Aswang, particularly the historization, must be done since the rewriting of Aswang stories in the $21^{\text {st }}$-century context may depict the changes and revival of the traits and functions of the typologies and archetypes that are registered upon the Aswang body and his image. Lastly, the analysis does not account for the overall discourse in relation to the canonical master trope of Aswang that is traced back from the early historical narratives of Spanish missionaries. The analysis of Moymoy attempts to reconcile its image in the context of fiction and historization about Aswang in the contemporary setting.

Finally, in light of Moymoy's story analysis, a new line of inquiry on the following areas emerged. First, conducting archival research on "cultural remapping" of Aswang characters in the $21^{\text {st }}$-century stories will theorize the shift in tropes and probably other symbolic deviations observed. The paradigm of shapeshifting will lead to designing the matrix of
Aswang typology that encompasses the pre-colonial up to the $21^{\text {st }}$-century Aswang portrayal in short stories and other forms of discourse such as film. Second, an exploration of the notion of contaminating Aswang will deepen our understanding of symbolic norms that will shed light on the perceptive view about ritual, order, and limitations in a specific culture. Lastly, a greater challenge calls for exploring more on the recurring patterns of Aswang typology and re-examine the meaning of the continuity and discontinuity of the traits, beliefs, and appearances depicted in various discourses concerning its reconstructed image.

\section{Conclusion}

As a "living folklore," Aswang is memorialized in the story of Matias. It presents the heroic archetypes that are depicted in the journey of Moymoy. His story implies that our beliefs about Aswang continuously emerge in the contemporary urban legend, which reinvents the Aswang character from a static master trope as "monstrous" to a "semi-ascension" as a monster hero. Given this, the reshaping of folk narratives, like the Aswang lore, makes some aspects of the character hero "queer," "deviant," and "ambiguous" yet exhibits symbolic ways of problematizing its role in the $21^{\text {st }}$-century context. Furthermore, the fluidity of Aswang image and its aesthetic patterns accommodate the versions and representations of Aswang that reposition its rhetoric to a contemporary rendition of heroic archetype. 
Altogether, the story of Moymoy still exhibits a core cultural pattern about our belief in Aswang. The exploration of his journey is evidence of the tenacity of culture, beliefs, and memories about the "monster" that continue to haunt us in the form of hybrid and cross-generic narratives in the $21^{\text {st }}$-century setting.

\section{References}

Alcina, S. J. Ignacio Francisco. History of the Bisayan People in the Philippine Islands. Translated by Cantius $\mathrm{J}$ Kobak, O. F. M. and Lucio Gutierrez O. P., Vol. 1. Manila, Philippines: UST Publishing House, 2004.

Arellano, Lisa. "The Heroic Monster: Dexter, Masculinity, and Violence." Television \& New Media 16, no. 2 (2015): $131-47$. https://doi.org/10.1177/1527476412 450192.

Azuma, Kentaro. "In Search of Aswang: A Ghost Story, Monster and Sorcerer in Philippine Society | Kyoto Review of Southeast Asia," October 3, 2012. https://kyotoreview.org/issue-12/insearch-of-aswang-a-ghost-storymonster-and-sorcerer-in-philippinesociety/.

Bacwaden, Joy Christine O. "Lumawig: The Culture Hero of the BontocIgorot." Philippine Studies 45, no. 3 (1997): 329-52. https://www.jstor.org/stable/42635050.

Barbour, Loren. "'Nemeses! Dragons! Symbolism!': Queering the Fantasy Hero Narrative in Nimona." Journal of Graphic Novels and Comics, June 25, 2020, 1-13. https://doi.org/10.1080/21504857.20 20.1786418.

Benczik, Vera. "Monsters Old and New The Changing Faces of Otherness and in Richard Matheson's I Am Legend and Its Film Adaptation." In Tradition and Innovation in
Literature: From Antiquity to the Present, edited by Pál Hegyi, 187203. Eötvös Loránd University: the Dean of Faculty of Humanities, 2020.

Bergstrand, Kelly, and James M. Jasper. "Villains, Victims, and Heroes in Character Theory and Affect Control Theory." Social Psychology Quarterly 81, no. 3 (2018): 228-47. https://doi.org/10.1177/0190272518 781050.

Campbell, Joseph. The Hero with $A$ Thousand Faces. Princeton: Princeton University Press, 2004.

Carroll, Michael P. "The Trickster as Selfish-Buffoon and Culture Hero." Ethos 12, no. 2 (1984): 105-31. https://www.jstor.org/stable/639961.

Childs, Brevard S. "The Etiological Tale Re-Examined." Vetus Testamentum 24, no. 4 (1974): 387-97. https://doi.org/10.2307/1517173.

Demetrio, Francisco. "Creation Myths among the Early Filipinos." Asian Folklore Studies 27, no. 1 (1968): 41-79.

https://doi.org/10.2307/1177800.

Demetrio, Francisco. "The Religious Dimensions of Some Philippine Folktales." Asian Folklore Studies 28, no. 1 (1969): 51-76. https://doi.org/10.2307/1177780.

Demetrio, Francisco R. "Shamans, Witches and Philippine Society." Philippine Studies 36, no. 3 (1988): 372-80.

https://www.jstor.org/stable/42633102.

de Gracia, Alta Grace. Aswang (Monsters) and Supernaturalisms: Nocturnal Deities. Manila, Philippines: Rex Book Store, Inc., 2011.

Higgins, Ryan S. "The Good, the God, and the Ugly: The Role of the Beloved Monster in the Ancient Near East and the Hebrew Bible." Interpretation: $A$ Journal of Bible and Theology 74, no. 2 (2020): 13245. 
https://doi.org/10.1177/0020964319 896307.

Inoue, Yoshitaka. "Contemporary Consciousness as Reflected in Images of the Vampire." Jung Journal: Culture \& Psyche 5, no. 4 (2011):

83-99.

https://doi.org/10.1525/jung.2011.5. 4.83.

Lim, Bliss Cua. "Queer Aswang Transmedia: Folklore as Camp." Kritika Kultura, no. 24 (2015): 180127.

https://doi.org/10.13185/KK2015.02 407.

Lynch, Frank. The Aswang Inquiry. Dallas: The Anvil Pub, 1998.

Macdonald, Charles J-H. "Folk Catholicism and Pre-Spanish Religions in the Philippines." Philippine Studies 52, no. 1 (2004): 78-93.

https://www.jstor.org/stable/42633685.

Magat, Margaret. "Balut: 'Fertilized Duck Eggs and Their Role in Filipino Culture." Western Folklore 61, no. 1 (2002):

63-96. https://doi.org/10.2307/1500289.

Matias, Segundo. Moymoy Lulumboy: Ang Batang Aswang. Metro Manila: Lampara Publishing House Inc, 2014.

McCrystal, Erica. "Hyde the Hero: Changing the Role of the ModernDay Monster." University of Toronto Quarterly 87, no. 1 (2018): 234-48. https://doi.org/10.3138/utq.87.1.234.

McGunnigle, Christopher. "The Difference between Heroes and Monsters: Marvel Monsters and Their Transition into the Superhero Genre." University of Toronto Quarterly 87, no. 1 (2018): 110-35. https://doi.org/10.3138/utq.87.1.110.

Meier, Isabelle. "The Classic, Banished, and Negative Hero." Jung Journal 15, no. 1 (2021): 36-48. https://doi.org/10.1080/19342039.20 21.1862593
Menez, Herminia. Exploration in Philippine Folklore. Manila: Ateneo de Manila University Press, 1996.

Patel, Alpesh Kantilal. "The Art of Queering Asian Mythology." In Global Encyclopedia of Lesbian, Gay, Bisexual, Transgender, and Queer (LGBTQ) History, edited by Howard Chiang, Anjali Arondekar, Marc Epprecht, Jennifer Evans, Ross G. Forman, Hanadi AlSamman, Emily Skidmore, and Zeb Tortorici', 10th ed., 127-34. Michigan: Gale: A Cengage Company, 2019.

Pertierra, Raul. "Viscera-Suckers and Female Sociality: The Philippine Asuang." Philippine Studies 31, no. 3 (1983): 319-37. https://www.jstor.org/stable/42633556.

Pierce, Sarah E. "From Demon to Daimon: A Mythic and Depth Psychological Analysis of the American Hero Vampire." Dissertation, Pacifica Graduate Institute, 2012. http://pqdtopen.proquest.com/doc/1 040729888. html?FMT=ABS.

Pugh, Tison. "The Queer Narrativity of the Hero's Journey in Nintendo's The Legend of Zelda Video Games." Journal of Narrative Theory 48, no. 2 (2018): 225-51. https://doi.org/10.1353/jnt.2018.0009.

Ramos, Maximo D. The Aswang Complex in the Philippine Folklore. Quezon City: Phoenix Publishing House Quezon City, 1990.

Reyes, Soledad S. "The Komiks and Retelling the Lore of the Folk." Philippine Studies 57, no. 3 (2009): 389-417.

https://www.jstor.org/stable/42634017.

Sabanpan-yu, Hope. "Performing the Body in Filipino Narratives: The Manananggal (Viscera Sucker) in Colonial Literature." UNITAS 90, no. 1 (2017): 57-73. https://doi.org/10.31944/2017901.ho sayu03. 
Segal, Robert A. "The Blurry Line Between Humans and Gods." Numen 60, no. 1 (2013): 39-53. https://doi.org/10.1163/1568527612341251.

Tolentino, Rolando. "Shake, Rattle and Roll Horror Franchise and the Specter of Nation-Formation in the Philippines." Humanities Diliman 13, no. 1 (2016): 134-52.

Van Tourhout, Benjamin. "The Hybrid Hero: A Contagious Counterexample." Journal of Humanistic Psychology 59, no. 4 (2019):

540-67. https://doi.org/10.1177/0022167817 718424.
Vučković, Dijana, and Ljiljana Pajović Dujović. "The Evolution of the Vampire from Stoker's Dracula to Meyer's Twilight Saga." CLCWeb: Comparative Literature and Culture 18, no. 3 (2016): 1-8. https://doi.org/10.7771/14814374.2836 . 